\title{
The Role of Grassy Habitats in Agroforestry
}

\author{
Nóra SZIGETI $^{\mathrm{a}^{*}}-$ Imre BERKI $^{\mathrm{b}}-$ Andrea VITYI $^{\mathrm{b}}-$ Dániel WINKLER $^{\mathrm{c}}$ \\ ${ }^{a}$ Institute of Advanced Studies, Köszeg, Hungary \\ ${ }^{\mathrm{b}}$ Institute of Environmental Protection and Natural Conservation, University of Sopron, Sopron, Hungary \\ ${ }^{\mathrm{c}}$ Institute of Wildlife Biology and Management, University of Sopron, Sopron, Hungary
}

\begin{abstract}
Planting shelterbelts on agricultural fields has long traditions in Hungary. The biodiversityenhancing effect of this type of agroforestry is intensively researched, but most of the results concentrate on tree species diversity and specific animal communities such as insects and birds. The characteristics of herbaceous vegetation and soil mesofauna related to shelterbelts are understudied; however, both communities play key roles in agricultural productivity. This study aimed to explore the diversity and species composition of these groups in shelterbelts and adjacent grassy and cropped habitats. Samples were taken inside and adjacent to a native and a non-native shelterbelt in an agricultural landscape. The results highlight that shelterbelt edges are at least as important as tree stands in preserving soil-related diversity. Native tree species composition shows slightly more favorable conditions concerning the examined communities. While the positive impact of shelterbelts on the agricultural productivity and the diversity of several animal communities has been proven, the appearance of forest-related herbaceous species in tree stands planted on cultivated fields is not expected, even after decades have passed. The research was supported by the Blue Planet Climate Protection Foundation.
\end{abstract}

\section{agroforestry / diversity / species composition / herbaceous vegeatation / soil mesofauna}

Kivonat - A gyepes élőhelyek szerepe az agrár-erdészetben. Magyarországon nagy hagyományokkal rendelkezik a mezőgazdasági területek védelme erdősávokkal. Az agrár-erdészet e típusának a biodiverzitást fokozó hatása intenzíven kutatott terület, de az eredmények többsége a fafajok sokféleségére és az állatközösségek szükebb körére, például rovarokra és madarakra koncentrál. Az erdősávok lágyszárú növényzete és a talajlakó mezofauna jellemzői még kevéssé vizsgált, holott mindkét közösség kulcsszerepet játszik a mezőgazdaság termelés eredményességében. A tanulmány célja ezen csoportok diverzitásának és fajösszetételének feltárása az erdősávokban és a csatlakozó gyepes és kultivált területeken. A mintavételezés mezőgazdasági területre ültetett őshonos és nem honos erdősávokban és környezetükben történt. Az eredmények azt tükrözik, hogy az erdősávok gyepes szegélyei legalább olyan fontosak a talajhoz kötődő diverzitás megörzésében, mint maga a faállomány. Az őshonos fafajösszetételű erdősáv kissé kedvezőbb képet mutat a vizsgált közösségek szempontjából. Míg az erdősávok pozitív hatása a szántóföldi termesztésre és számos állatközösség diverzitására bizonyított, az erdőhöz kötődő lágyszárú fajok megjelenése még évtizedek után sem várható a mezőgazdasági területekre ültetett faállományokban. A kutatást a Kék Bolygó Klímavédelmi Alapítvány támogatta.

agrár-erdészet / diverzitás / fajösszetétel / lágyszárú növényzet / talajlakó mezofauna

\footnotetext{
* Corresponding author: szigetinora31@gmail.com; H-9730 KÖSZEG, Chernel u. 14, Hungary
} 


\section{INTRODUCTION}

Agroecological systems can provide the opportunity to maintain productivity in a sustainable form (Ball et al. 2018). Agroforestry, a promising aspect of climate change adaptation, integrates woody vegetation into agricultural cultivation, thereby exploiting its various economic, social and ecological benefits. Agroforestry can even revive degraded lands by improving the physical quality of soil once the characteristics of soil aggregate and biological activity are taken into account (Cherubin et al. 2019).

Based on several research results (Feliciano et al. 2018, Jezeer et al. 2019, Elagib - AlSaidi 2020, Tschora - Cherubini 2020), the advantages of agroforestry can be summarised as follows:

- Soil erosion and runoff control, defending soil from losses of water and nutrients

- Maintaining biological activity, physical properties, and nutrient content of soil for fertility

- Micro-climate regulating

- Providing fodder and shelter for livestock

- Insect pest control

- Eroded and degraded land rehabilitation

- Diversification and stabilisation of farm economy via multiple products

- Promoting nature conservation and biodiversity by providing a framework for above ground and belowground biodiversity

Shelterbelts are the most significant representatives of arable agroforestry in Hungary. While the weed vegetation of intensively cultivated agricultural areas has been widely researched (Pinke - Pál 2005, Pinke et al. 2012, Király - Király 2012, Nagy et al. 2017, Krähmer et al. 2019), research concentrated on shelterbelts has been largely limited to tree species composition and structure surveys (Takács 2008, Jánoska 2012).

According to the technical development of weed management, the number of species adapted to agricultural land use has experienced a significant decline in recent decades (Marshall 2002, Pinke - Pál 2005). Field edges that form a boundary structure with associated habitats can positively affect the weed flora (Marshall - Moonen 2002). These edges offer refuges for many weed species in intensely cultivated environments (Marshall Arnold 1995).

In appropriate conditions, shelterbelts produce a corridor effect by providing connectivity between woody patches, thereby increasing tree stand area and offering an edge habitat in agricultural landscapes (Damschen 2013). As these corridors increase the number of native plant species, they are an essential tool for biodiversity preservation (Damschen et al. 2006). The presence, absence, or diversity of herbaceous plants can strongly influence the composition and richness of the food chain upon which it is based, and thus the overall biodiversity of the agroforestry system. Therefore, the study of the herbaceous diversity of shelterbelts in agricultural environments is sensible. Acari and Collembola communities play key roles in support productivity under nutrient-poor conditions. Nevertheless, even minor changes in the composition and abundance of these species can significantly affect the local mobilization of nutrients (Heneghan - Bolger 1998). Several studies highlight the role of the food chain and the presence of natural enemies of pests, or even alien, invasive species in agriculture (Schonrogge et al. 1996, Willis - Memmott 2005, Morris et al. 2004). While some weeds can uniquely support the life cycle of a range of insect species, weed diversity strictly correlates with the heterogeneity of plant communities, which affects insectivorous bird communities and other animal communities (Marshall et al. 2003). Also, the presence of seeds is of key importance for granivorous bird species, especially during winter (Buckingham et al. 2011). Many bird species feed primarily on seeds and other parts of plants 
as adults, but young individuals need invertebrate food. In addition to the diversity and species composition of vegetation, the density and structure of a plant community are very important for many arthropods that, in turn, provide nutrients for vertebrate animals (Marshall et al. 2003). According to the dispersal of the hedge flora, Marshall (1989) found that the majority of the plants do not spread into the crop field. Some species have limited dispersal into crop areas, and a lower number of species occur as serious field weeds. The field margin, as ecotone, often supports species characteristic to the adjacent habitats and other species that are not present in either adjacent habitats. Thus, a field margin containing grassland, woodland, and ruderal or segetal plants can be more diverse than either the crop field or the woody boundary. Thus, if woody vegetation (trees or shrubs as hedges) border the agricultural fields, the ideal structure of the margin consists of the woody boundary, a nature conservation strip, and the crop edge, which should be completed with a grassy or wildflower margin strip for wildlife or environmental objectives, between the boundary and the crop field. This strip should be free of chemicals (Marshall - Moonen 2002). The aim of the study was to assess the role of shelterbelts and their grassy edges in increasing the soil-related diversity in an intensively managed agricultural area.

\section{MATERIALS AND METHODS}

\subsection{Location of the study area}

Surveys were conducted in an intensively managed agricultural landscape in northwest Hungary (Figure 1). Mosonszolnok and its surroundings are typical of the Little Hungarian Plain. An important feature of the sample area is the significant climatic drought, which is caused by the frequent descending westward airflow from the Eastern Alps (Péczeli 1975). In addition, the sediments and alluvium in this area are calcareous, which can increase the effect of climatic drought.

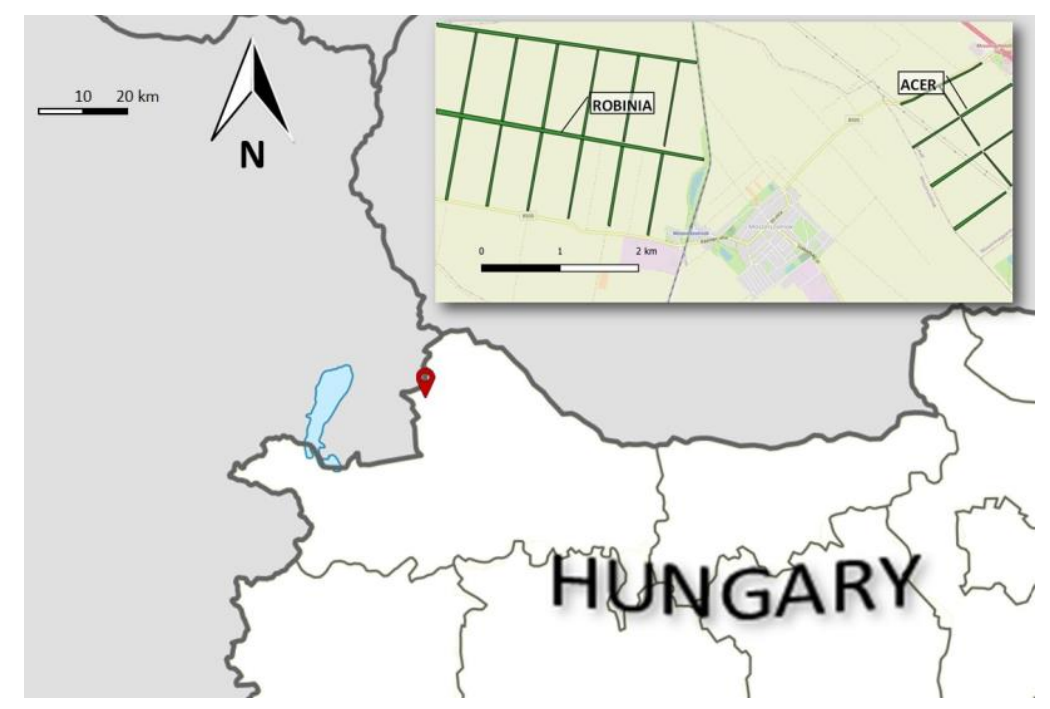

Figure 1. Location of the test site

Sandy muddy loess covers the gravel-based flat alluvial cone (Pécsi 1975). Topsoil depth determines the land use: $40-70 \mathrm{~cm}$ deep topsoil is only suitable for poor quality pastures, or where other conditions allow, peach and grape cultivation (Miklay - Molnár 1968). This explains the presence of former pasture fragments on the test site. Agricultural cultivation determines the current appearance of the landscape. The few existing semi-natural habitats are 
highly fragmented. A variety of grains are grown on the monocrop fields. Shelterbelts with different tree species compositions provide a poor diversity of the landscape. The shelterbelts here consist of tree stands that are approximately 50 years old and were established primarily field protection. The current study examined two of these shelterbelts.

Surveys were conducted within the two shelterbelts and in the adjacent habitats: in the grassy edge on both sides of the shelterbelts (EDGE) and in the cultivated fields, $10 \mathrm{~m}$ distance from the trees (CULT), with tree repeats (Figure 2).

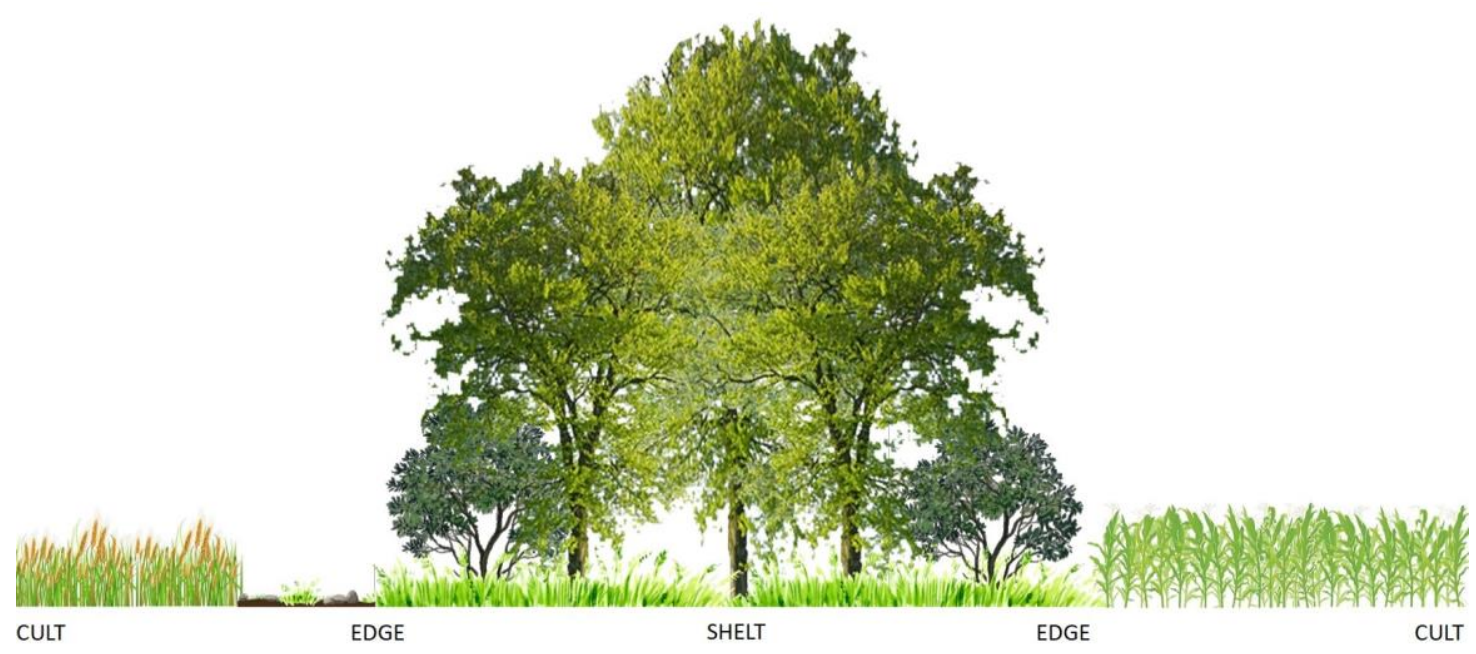

Figure 2. Location of the sampling plots in the shelterbelts and adjacent habitats

\subsection{Soil properties}

Soil samples were taken from the soil surface $(0-10 \mathrm{~cm}$ depth) to measure soil parameters. Table 1 summarises the examined characteristics and the measuring methods.

Table 1. Measured soil parameters and methods

\begin{tabular}{|c|c|}
\hline Soil parameter & Measuring method \\
\hline $\mathrm{pH}$ & Ratio of 1:5 soils to distilled water \\
\hline Soil organic matter content (SOM) & Potassium dichromate capacity method (Búzás 1988) \\
\hline Available nitrogen $\left(\mathrm{NO}_{3}{ }^{-}+\mathrm{NH}_{4}^{+}\right)$ & $\begin{array}{lll}\text { Parnas-Wagner } & \text { distillation } & \text { apparatus } \\
\text { (Houba et al. 1986) } & \end{array}$ \\
\hline Available phosphorus & Ammonium-lactate solution (Hungarian Standard \\
\hline Available potassium & MSZ 20135:1999 \\
\hline Particle size distribution & Robinson's pipette method (Pansu - Gautheyrou 2007) \\
\hline Soil moisture & $\begin{array}{l}\text { Gravimetric method, after heating the samples at } \\
105^{\circ} \mathrm{C} \text { for } 24 \mathrm{~h} \text { (Black 1965) }\end{array}$ \\
\hline
\end{tabular}

\subsection{Vegetation}

Coenological data were collected in $25 \mathrm{~m}^{2}$ quadrats with three repeats in all plots (Figure 2). Diversity profiles were used to compare the herb layers of the different habitats, calculated with PAST software. PAST uses the exponential of the so-called Renyi index, including the number of species, Shannon diversity, quadratic diversity, and Berger-Parker diversity. The value of the index depends upon the parameter "alpha". The diversity of the studied communities can be ranked in a partial order with this method (Tóthmérész 2013).

The social behaviour type (SBT) categories are derived from the CSR plant functional system (Grime 1979), adapted to the Pannonian flora by Borhidi (1995). The category of each 
plant species was determined based on the role the plant species plays in the communities. The naturalness of the species as well as how it linked to the habitat were also considered. The number and proportion of categories represented in a habitat provide information about the stability, the level of disturbance, or the deviation from the natural state of the community. The specialists (S), competitors (C), generalists (G), and natural pioneers (NP) - with naturalness values of $+6,+5,+4$, and +3 , respectively - are all characteristic to natural habitats. Disturbance tolerants (DT) and weeds (W) appear in disturbed, secondary, and artificial habitats, but still have a positive (2 and 1) naturalness value. Introduced alien species (I), adventives (A), ruderal competitors (RC), and aggressive alien species (AC) represent the most unfavorable categories with negative values: $-1,-1,-2$ and -3 , respectively. The classification of each species was obtained from the Hungarian Flora Database (Horváth et al. 1995). The proportion of species belonging to the different categories in a habitat is displayed with stacked column charts, where the total species number of the examined habitat and the distribution of the species numbers by the SBT categories can be examined simultaneously. (In the case of a small number of species, the SBT categories are not given in the database, which results in a difference between the SBT total number of species and the total number in diversity analysis).

RDA was chosen to analyse the relationship between species composition environmental descriptors observed at the same locations. The species abundance matrix was transformed with the Hellinger method. Hellinger transformation is recommended as a basis for ordination as permits the exploration of the relationships of species to explanatory variables (Legendre Gallagher 2001). The environmental factors included in the analysis were the impact of measured soil parameters (Table 2), the cover of the different tree species, exposure, and the presence or absence of an earth road separating the examined plot from the cultivated area.

\subsection{Soil mesofauna}

One hundred cubic centimetres of soil samples were collected with a cylindrical soil core sampler in each coenological quadrat. The microarthropods were extracted with BerleseTullgren funnels to $96 \%$ ethanol for two weeks. The specimens were classified into major taxonomic groups, while Collembola individuals were determined to the species level. Collembolan diversity was measured with the same method used for herbaceous diversity.

QBS-ar index was employed to evaluate the soil's biological quality (Parisi 2001, Menta et al. 2017). Based on their adaptation to the soil environment, microarthropods are classified into different morphotypes, and characterized with an ecomorphological (EMI) value. The sum of the obtained EMI scores gives the QBS-ar index of the examined sample (Annex IV).

Redundancy analysis was applied to assess the impact of environmental factors on collembolan species composition, with the same method used for herbaceous plants.

\section{RESULTS AND DISCUSSION}

\subsection{Soil habitat condition}

The soil parameters (Table 2) show that all of the plots have a neutral to slightly alkaline $\mathrm{pH}$. The texture of the soils is sandy-silty with a low carbonate content. Cultivated plots have the lowest SOM value and, at the same time, the highest phosphorus and potassium content due to fertilization. 


\subsection{Woody vegetation}

The non-native tree stand (ROBINIA) is dominated by black locust (Robinia pseudoacacia) and green ash (Fraxinus pennsylvanica) in the canopy layer. The shrub layer is poor in species; Ligustrum vulgare, Elaeagnus angustifolia, and Maclura pomifera can be found with low cover. The native shelterbelt (ACER) is composed of native tree species, where field maple (Acer campestre), field elm (Ulmus minor), Norway maple (Acer platanoides) and Turkey oak (Quercus cerris) form the canopy layer. The shrub layer is weak, similar to the non-native stand; besides Ligustrum vulgare, only Sambucus nigra and Prunus spinosa appear. The cover values of the canopy and shrub layers in the shelterbelts can be found in Table 3.

Table 2. Measured values of the soil parameters

\begin{tabular}{|c|c|c|c|c|c|c|c|c|c|c|c|c|}
\hline & Plot & $\begin{array}{c}\mathrm{pH} \\
\left(\mathrm{H}_{2} \mathrm{O}\right)\end{array}$ & $\begin{array}{c}\mathrm{CaCO}_{3} \\
(\%)\end{array}$ & SOM & $\begin{array}{l}\mathrm{NH}_{4}{ }^{+}+ \\
\mathrm{NO}_{3}{ }^{-} \mathrm{N} \\
(\mathrm{mg} / \mathrm{kg})\end{array}$ & $\begin{array}{c}\mathrm{AL} \mathrm{P} \\
\left(\mathrm{mg} \mathrm{P}_{2} \mathrm{O}_{5} / \mathrm{kg}\right)\end{array}$ & $\begin{array}{c}\mathrm{AL} \mathrm{K} \\
\left(\mathrm{mg} \mathrm{K} \mathrm{K}_{2} \mathrm{O} / \mathrm{kg}\right)\end{array}$ & A\% & $\mathrm{I} \%$ & FH\% & DH\% & Moist \\
\hline \multirow{5}{*}{ 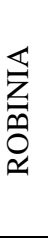 } & CULT & 7.76 & 3.28 & 0.90 & 7.10 & 542.00 & 614.67 & 29.33 & 23.00 & 43.33 & 4.33 & 15.87 \\
\hline & EDGE & 7.46 & 5.51 & 1.57 & 8.80 & 413.67 & 541.00 & 27.33 & 18.00 & 47.00 & 7.67 & 13.73 \\
\hline & SHELT & 7.43 & 3.33 & 2.10 & 9.70 & 125.33 & 615.67 & 25.33 & 23.00 & 48.00 & 3.67 & 13.67 \\
\hline & EDGE & 7.42 & 4.96 & 1.77 & 8.43 & 449.67 & 523.00 & 27.67 & 17.00 & 48.00 & 7.33 & 13.04 \\
\hline & CULT & 7.71 & 2.52 & 0.87 & 7.27 & 561.33 & 688.00 & 30.00 & 22.67 & 41.67 & 5.67 & 14.46 \\
\hline \multirow{5}{*}{ 选 } & CULT & 7.51 & 1.63 & 0.93 & 6.63 & 584.67 & 770.00 & 31.33 & 26.33 & 38.00 & 4.67 & 12.13 \\
\hline & EDGE & 7.50 & 7.20 & 1.67 & 8.57 & 314.33 & 434.00 & 29.33 & 19.67 & 42.33 & 8.67 & 11.42 \\
\hline & SHELT & 7.51 & 5.99 & 1.97 & 10.07 & 133.67 & 513.67 & 23.33 & 22.67 & 43.00 & 10.67 & 10.76 \\
\hline & EDGE & 7.52 & 7.08 & 1.67 & 8.13 & 369.67 & 463.00 & 29.33 & 20.33 & 42.33 & 8.00 & 12.70 \\
\hline & CULT & 7.49 & 2.37 & 0.97 & 7.17 & 537.33 & 735.33 & 32.00 & 26.33 & 36.67 & 5.00 & 12.50 \\
\hline
\end{tabular}

Table 3. Cover values of the canopy (A) and shrub (B) layers in the shelterbelts

\begin{tabular}{|c|c|c|c|c|c|}
\hline \multirow[t]{2}{*}{ Layer } & \multicolumn{2}{|c|}{ Cover $(\%)$ of layer } & \multirow[t]{2}{*}{ Species } & \multicolumn{2}{|c|}{ Cover $(\%)$ of species } \\
\hline & ROBINIA & ACER & & ROBINIA & ACER \\
\hline \multirow{9}{*}{$\begin{array}{c}\mathrm{A} \\
(10-15 \mathrm{~m})\end{array}$} & \multirow{9}{*}{$80 \%$} & \multirow{9}{*}{$80 \%$} & Robinia pseudoacacia & 60 & \\
\hline & & & Fraxinus pennsylvanica & 20 & \\
\hline & & & Acer platanoides & 5 & \\
\hline & & & Maclura pomifera & 5 & \\
\hline & & & Gleditsia triacanthos & 5 & \\
\hline & & & Acer campestre & & 50 \\
\hline & & & Ulmus minor & & 10 \\
\hline & & & Acer platanoides & & 10 \\
\hline & & & Quercus cerris & & 10 \\
\hline \multirow{5}{*}{ B } & \multirow{5}{*}{$40 \%$} & \multirow{5}{*}{$20 \%$} & Ligustrum vulgare & 20 & 20 \\
\hline & & & Sambucus nigra & & 10 \\
\hline & & & Prunus spinosa & & 10 \\
\hline & & & Elaeagnus angustifolia & 10 & \\
\hline & & & Maclura pomifera & 5 & \\
\hline
\end{tabular}

\subsection{Herbaceous diversity}

In total, 50 herbaceous species appeared in the examined quadrats. Only 14 of these were present inside the shelterbelts, while 44 species were found in the grassy edges (Annex II).

In both non-native (ROBINIA) and native (ACER) shelterbelts, the herbaceous diversity of the woody habitat (SHELT) is lower than that of grassy edges (EDGE). Both shelterbelts are very poor in species. This is similar to the results of Carlier - Moran (2019), who found 
the herbaceous vegetation of hedgerows very poor in species. The cultivated areas adjacent to ROBINIA were almost totally weed-free in all of the three periods (Figure 3). This may indicate a more intensive weed management activity in the surroundings of this shelterbelt and can explain the lower diversity of the edges and field margins compared to ACER.
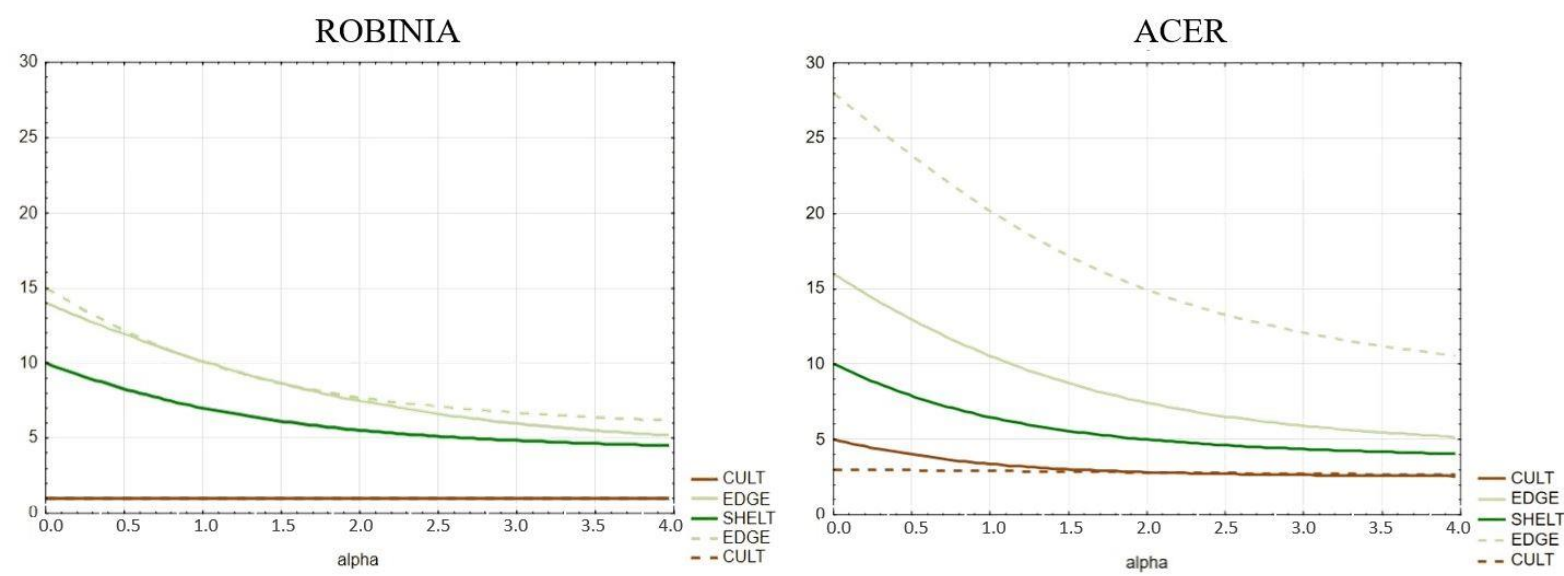

Figure 3. The diversity profiles of the herbaceous vegetation in the shelterbelts and adjacent habitats

The non-woody field margins, grassy edges, and roadside habitats contribute significantly more to the weed diversity of the landscape than shelterbelts do. Romero et al. (2008) also reflected the significance of field margins in enhancing the diversity of the agricultural land, especially in the case of organic farming. Besides increasing weed diversity, Fried et al. (2009) found that field margins act as a refuge for agricultural weed species. A similar phenomenon was experienced at our test site, where numerous segetal weed species were found in the grassy edges, but none of these appeared inside the shelterbelts. Typically forestrelated species were not found in the shelterbelts either, which can be explained by the effect of fragmentation and by the fact that most of the forest-related herbaceous species colonise the newly planted woodlands very slowly (Wilson 2019). On the other hand, the agricultural weeds are adapted to open habitats and extensive cultivation (Pinke - Pál 2005). Thus, the conditions in the core of a shelterbelt are not appropriate for these species. This results in lower diversity in the shelterbelts than in the adjacent open habitats.

The herbaceous layer of black locust forests is typically poor in species due to the allelopathic effect of this tree species (Ferus et al. 2019), which causes the homogenization of the plant forest biota (Benesperi et al. 2012). This phenomenon is not evident in the case of the examined shelterbelts. Morrison - Flores (2013) found a significant difference regarding diversity and species composition in the understorey layer for native windbreaks; the appearance of invasive herbaceous species was higher in non-native shelterbelts. This survey was not limited to herbaceous species, but included tree seedlings as well. This method naturally results in a more favourable species construction of the native tree plantations.

\subsection{Soil microarthropods}

Fifty-five Collembola species were found in the examined soil samples. Four of these appeared only in the native shelterbelts, four in the non-native shelterbelts, and 18 only in non-woody habitats. Six of the species were found only in the grassy edges of the shelterbelts, and three were uncial to cultivated plots (Annex III). According to collembolan diversity, the native shelterbelt (ACER) exhibits slightly better conditions than the non-native belt (ROBINIA). The cultivated plots (CULT) are very poor in species, but the grassy edges of the shelterbelts are quite diverse in most cases (Figure 4). 

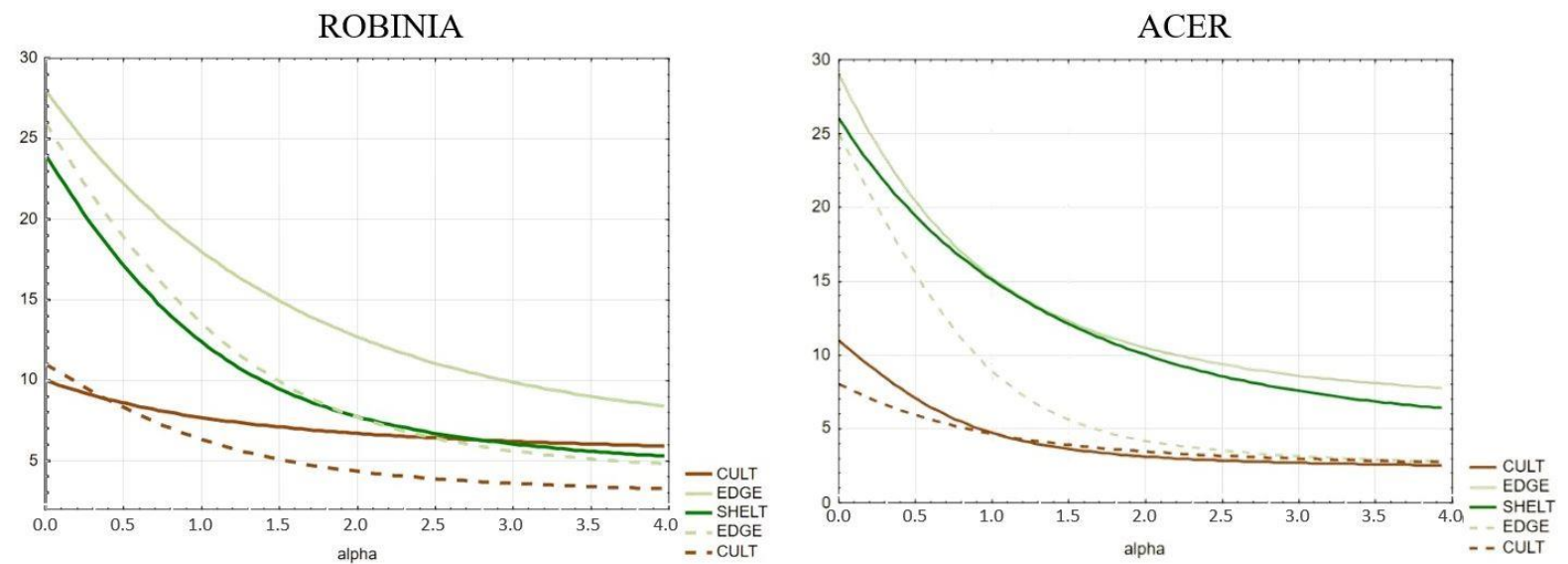

Figure 4. The diversity profiles of springtails (Collembola) in the shelterbelts and adjacent habitats

The grassy edges of shelterbelts are at least as favourable a habitat for Collembola communities as the core of the shelterbelts are, which is similar to the results of herbaceous diversity examinations. Just a few forest-related Collembola species appeared in the soil of the shelterbelts. The reason for this phenomenon is the lack of forest habitats in the landscape and, similar to forest-related herb species, the weak dispersal ability of euedaphic Collembola species (Auclerc et al. 2009). The majority of the Collembola species are pioneers in both native and non-native shelterbelts, which coincides with the results of Olejniczak (2007). In terms of species richness and diversity, the maple shelterbelt is in a slightly more favourable condition than the black locust stand. Lazzaro et al. (2018) reported that this phenomenon is more significant in forest stands; the study found a remarkable decrease in hemiedaphic and euedaphic microarthropod groups, such as Protura, Acarina, Collembola, Diplopoda, Coleoptera, and Thysanoptera in black locust forests, which also can be explained with the allelopathic effect of black locust. Secondary metabolites (e.g., toxalbumins, robin) produced and released by black locust (Hui et al. 2004) often limit the diversity and abundance of microarthropods (Nasiri et al. 2005, Litt et al. 2014). Overall, both shelterbelt types play an essential role in collembolan diversity in agricultural landscapes. Several studies highlight the impact of tree rows in the migration of springtails from woody habitats to cultivated fields (Alvarez et al. 2000, Olejniczak 2007), which positively affects organic degradation and nutrient recycling processes (Menta 2012).

\subsection{Qualitative parameters}

The majority of the herbaceous plants appearing in the environment of the examined shelterbelts are disturbance tolerant (DT) and weed (W) species, such as Arrhenatherum elatius, Veronica arvensis, Lolium perenne, Galium aparine, or Lamium purpureum. The specialist (S) and natural competitor (C) categories are totally absent, while ruderal competitors (RC), like Amaranthus retroflexus, Bromus sterilis, and Convulvulus arvensis appear in all examined plots. The cultivated fields are extremely poor in herbaceous species due to weed management. The only generalist appearing in the maple shelterbelt is Symphytum officinale, while in the grassy edges, this category is represented by two species: Poa pratensis and Thymus glabra. Segetal weed species Consolida regalis, Fumaria vaillantii, and Viola arvensis appeared only in the grassy edges.

Regarding microarthropods, 20 taxa were present in the examined soil samples, of which Collembola and Acari are the most abundant groups. Both the biological quality of soil (QBSar index) and the distribution of herbaceous plant species by social behaviour type (SBT) 
categories reveal the importance of shelterbelts and grassy edges in agroforestry as these habitats increase soil-related diversity in the agricultural land (Figure 5).
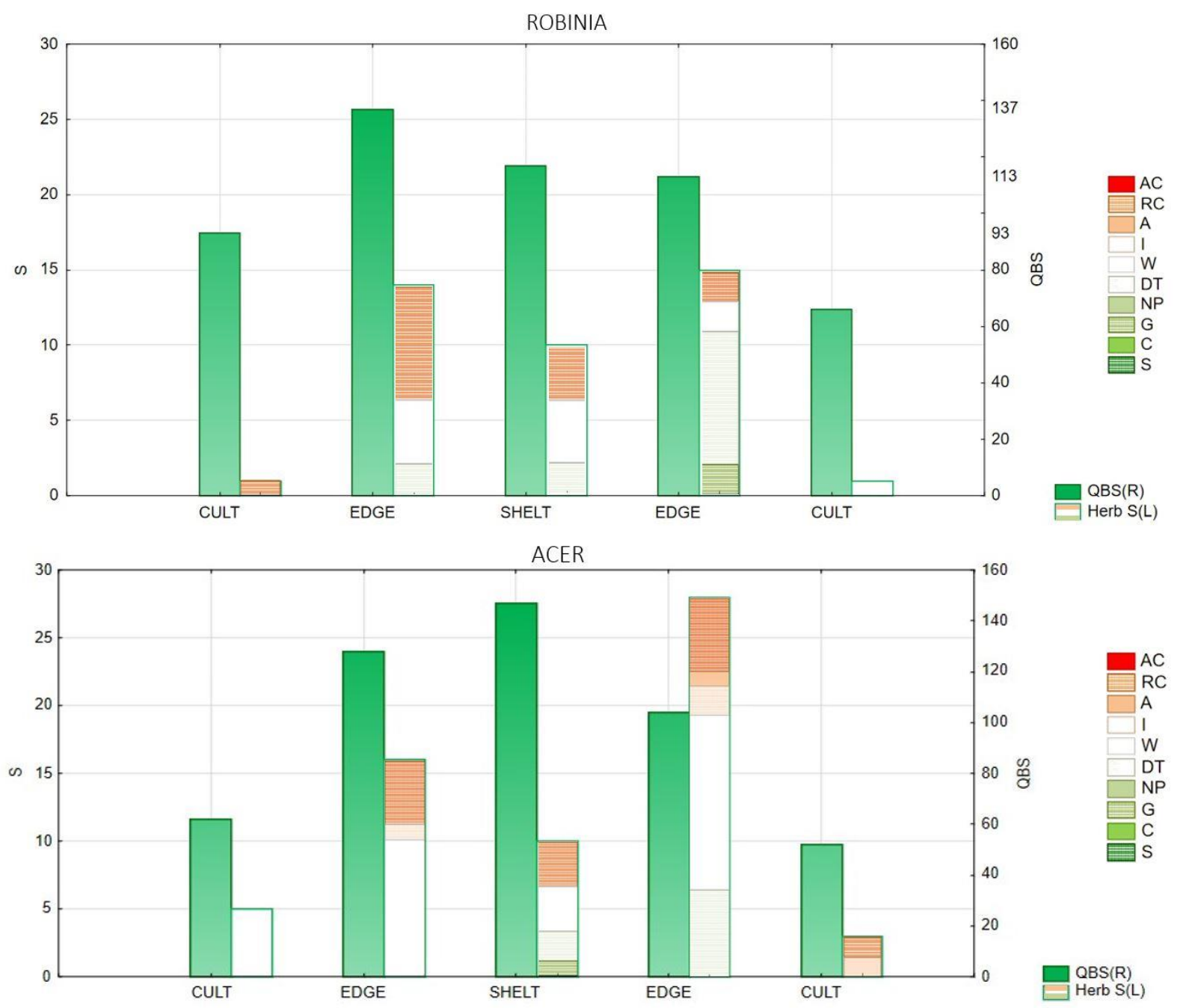

Figure 5. QBS-ar index and the distribution of herbaceous species by SBT categories in the non-native (ROBINIA) and native (ACER) shelterbelts and adjacent habitats

The qualitative traits of herbaceous and microarthropod communities show slightly more favourable conditions in the native shelterbelt. The QBS-ar index of the maple shelterbelt is the highest among the examined plots, while in some cases, this value is higher in the grassy edges than in the black locust belt. The number of ruderal competitor (RC) herbaceous species is similar in the different plots, but the number of native weeds is significantly higher in the edges than it is in the shelterbelts or cultivated fields.

\subsection{Species composition}

Among soil parameters, $\mathrm{CaCO}_{3}$ and $\mathrm{pH}$ are inversely correlating and determining factors for both communities (Figure 6). However, in the case of vegetation, this relation should be indirect, as the differences in the values are negligible. In practice, this linkage can result from differences in the level of disturbance, which cannot be measured and added to the analysis as a determining factor. The grassy vegetation and the presence of an earth road between the crop field and the edge are also important features. Black locust strongly affects the 
collembolan community, contrary to the herbaceous species composition, which is not determined by the tree species primarily.
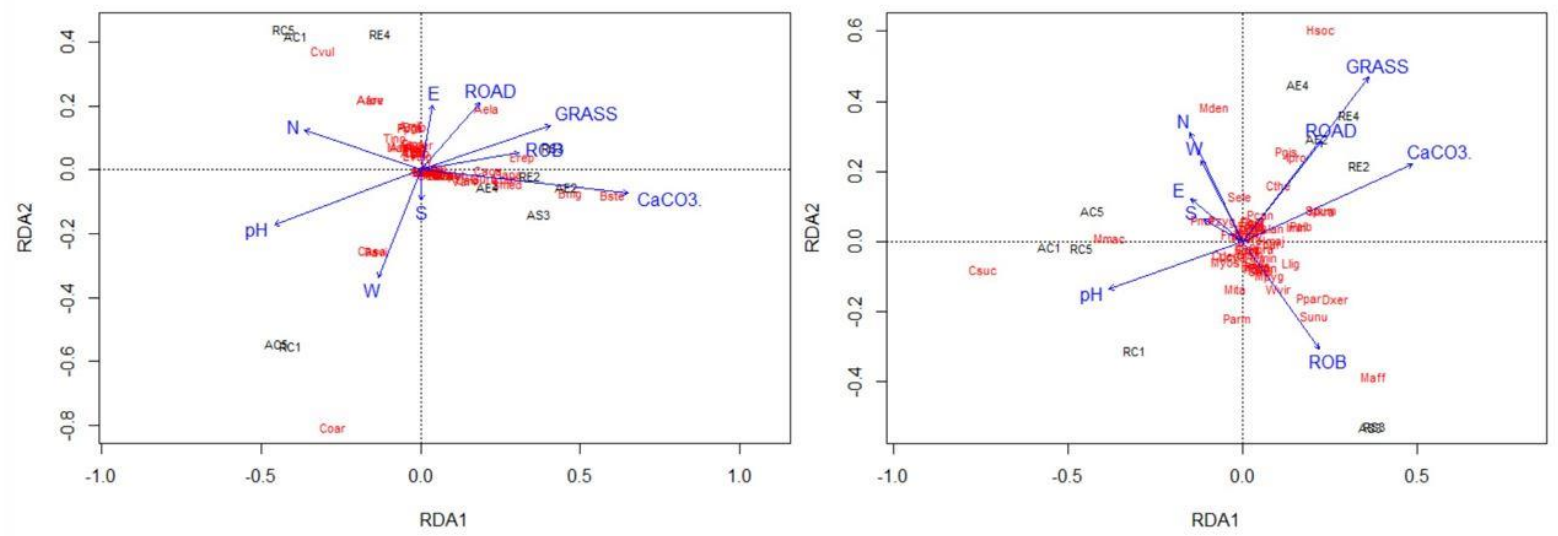

Figure 6. Redundancy analysis of the herbaceous (left) and collembolan (right) communities. Abbreviations: $\mathrm{pH}$ : soil $\mathrm{pH} ; \mathrm{CaCO}_{3}$ : calcium carbonate content of the soil; $\mathrm{N}, \mathrm{E}, \mathrm{W}$ : northern, western and eastern exposure; ROAD: an earth road separating the shelterbelt edges from crop field; GRASS: the vegetation cover is grass, ROB: the cover value of black locust.

Several studies confirm the positive correlation between herbaceous and Collembola communities (Salamon et al. 2004, Eisenhauer et al. 2011, Perez et al. 2013). The impact of the presence of an earth road between the cultivated field and the edge on the edge flora is confirmed by Sutyinszki et al. (2013), who found that line facilities mitigate the negative effects coming from cultivated fields and, thereby, support the formation of a more diverse edge flora. The sensitivity of Collembola species to herbicides (Frampton et al. 2006) explains that the presence of an earth road determines collembolan species composition. The majority of the herbaceous plants appearing in the environment of the examined shelterbelts are disturbance tolerant (DT) and weed (W) species, such as Arrhenatherum elatius, Veronica arvensis.

\section{CONCLUSIONS}

The results showed that the herbaceous flora of shelterbelts planted in agricultural areas is weak, and forest-related herbaceous species do not appear in such tree stands. Despite the allelopathic and nitrogen-fixing effect of black locust, which can lead to habitat transformations, the herbaceous layer is similar to that of the native shelterbelts. The cause of the species-poor herbaceous vegetation in shelterbelts is complex. The main factors are fragmentation, the negative effects of the agricultural surroundings, and the lack of immediate connections to former semi-natural habitats. In addition, the drying climate and the increased game population may contribute to the degradation of the herbaceous flora. The role of nonwoody habitats in preserving the agricultural weed flora is higher than that of the shelterbelts. The herbaceous diversity of an agroforestry system can be increased with grassy edges, where a species-rich, even segetal weed community can develop. However, some forest-related Collembola species appeared in the shelterbelts, and the grassy edges are also important habitats for soil mesofauna. The choice of tree species has a greater impact on microarthropods than on herbaceous plants. Overall, chemical-free, extensively mowed grassy strips can contribute significantly to the diversity of the soil-related communities of an agroforestry system. 
Acknowledgements: The project was supported by the EFOP-3.6.2-16-2017-00018 in University of Sopron project.

\section{REFERENCES}

AlvareZ, T. - FRAMPTON, G.K. - GOULSON, D. (2000): The role of hedgerows in the recolonization of arable fields by epigeal Collembola. Pedobiologia 44: 516-526. https://doi.org/10.1078/S0031$\underline{\text { 4056(04)70068-2 }}$

Auclerc, A. - PONGE, J-F. - BAROT, S. - DubS, F. (2009): Experimental assessment of habitat preference and dispersal ability of soil springtails. Soil Biology and Biochemistry 41 (8): 15961604. https://doi.org/10.1016/j.soilbio.2009.04.017

BALl, B.C. - HARGREAVES, P.R. - WATSON, C.A. (2018): A framework of connections between soil and people can help improve sustainability of the food system and soil functions. Ambio 47: 269283. https://doi.org/10.1007/s13280-017-0965-Z

BENESPERI, R. - GiUliani, C. - ZANETTI, S. - GENNAI, M. - LiPPI, M.M. - Guidi, T. - NASCIMBENE, J. - FoGGI, B. (2012): Forest plant diversity is threatened by Robinia pseudoacacia L. (Black locust) invasion. Biodiversity and Conservation 21 (14): 3555-3568. http://doi.org/10.1007/s10531-012-0380-5.

BERKI, I. (2020): A Mosoni-sík természetföldrajzi tényezőinek összhatása [The combined effect of the natural geographical factors of the Moson plain]. In. FÜHRER, E. (ed): Magyarország erdészeti tájai III. Kisalföld Erdészeti Tájcsoport. Kézirat (in Hungarian)

BLACK, C.A. (1965): Methods of Soil Analysis: Part I Physical and mineralogical properties. American Society of Agronomy, Madison, Wisconsin, USA.

BORHIDI, A. (1995): Social behaviour types, the naturalness and relative ecological indicator values of the higher plants in the Hungarian flora. Acta Botanica Hungarica 39: 97-181.

BuckinghaM, DL. - Bentley, S. - DoDD, S. - PEACH, W.J. (2011): Seeded ryegrass swards allow granivorous birds to winter in agriculturally improved grassland landscapes. Agriculture, Ecosystems and Environment 142 (3-4): 256-265. https://doi.org/10.1016/j.agee.2011.05.017

BuZÁs, I. (ed). (1988): Soil- and agrochemical methods manual. Part 2. Mezőgazdasági Kiadó, Budapest. (in Hungarian)

CARLIER, J. - MORAN, J. (2019): Hedgerow typology and condition analysis to inform greenway design in rural landscapes. Journal of Environmental Management 247: 790-803. https://doi.org/10.1016/j.jenvman.2019.06.116

Cherubin, M.R. - Chavarro-Bermeo, J.P. - Silva-Olaya, A.M. (2019): Agroforestry systems improve soil physical quality in northwestern Colombian Amazon. Agroforestry Systems 93: 1741-1753 https://doi.org/10.1007/s10457-018-0282-y

DAMSCHEN, E.I. - HADDAD, N.M. - ORROCK, J.L. - TEWKSBURY, J.J. - LEVEY, D.J. (2006): Corridors Increase Plant Species Richness at Large Scales. Science 313: 1284-1286. https://doi.org/10.1126/science. 1130098

DAMSCHEN, E.I. (2013) Lanscape corridors. In: LEVIN, S.A.: Encyclopedia of Biodiversity 467-475. Academic Press https://doi.org/10.1016/B978-0-12-384719-5.00385-3

Eisenhauer, N. - Yee, K. - Johnson, E.A. - MARAun, M. - PARKONSON, D. - Straube, D. SCHEU, S. (2011): Positive relationship between herbaceous layer diversity and the performance of soil biota in a temperate forest. Soil Biology and Biochemistry 43: 462-465. https://doi.org/10.1016/j.soilbio.2010.10.018

ElAGIB, N.A. - AL-SAIDI, M. (2020): Balancing the benefits from the water-energy-land-food nexus through agroforestry in the Sahel. Science of the Total Environment 742: 140509. https://doi.org/10.1016/j.scitotenv.2020.140509 
ERDÉlYI, M. - RÓNAI, A. - SOMOGYI, S. (1975): A Győri-medence felszín alatti vizei [Groundwater of the Győr basin]. In: ÁDÁM, L.- MAROSI, S (eds): Magyarország tájföldrajza 3. A Kisalföld és a Nyugat-magyarországi-peremvidék. p. 605 (in Hungarian)

FELICIANO, D. - LEDO, A. - HILLIER, J. - NAYAK, D.R. (2018): Which agroforestry options give the greatest soil and above ground carbon benefits in different world regions? Agriculture, Ecosystems and Environment 254: 117-129. https://doi.org/10.1016/j.agee.2017.11.032

Ferus, P. - Bosiakova, D. - Konopkova, J. - HotKA, P. - Kósa, G. - MelnyKova, N. - Kots, S. (2019): Allelopathic interactions of invasive black locust (Robinia pseudoacacia L.) with secondary aliens: the physiological background. Acta Physiologiae Plantarum 41: 182. https://doi.org/10.1007/s11738-019-2974-y

FRAMPTON, G. K. - JÄNSCH, S -, SCOTT-FoRDSMAND, J. J. - RÖMBKE, J. - VAN DEN BRINK, P. J. (2006): Effects of pesticides on soil invertebrates in laboratory studies: a review and analysis using species sensitivity distributions. Environmental Toxicology and Chemistry 25 (9): 2480. https://doi.org/10.1897/05-438R.1

Fried, G. - PetiT, S. - Dessaint, F. - Reboud, X. (2009): Arable weed decline in Northern France: Crop edges as refugia for weed conservation? Biological Conservation 142 (1): 238-243. https://doi.org/10.1016/j.biocon.2008.09.029

GRIME, J.P. (1979): Plant Strategies, Vegetation Processes, and Ecosystem Properties. Wiley, New York.

HENEGHAN, L. - BOLGER, T. (1998): Soil microarthropod contribution to forest ecosystem processes: the importance of observational scale. Plant and Soil 205 (2): 113-124. https://doi.org/10.1023/A:1004374912571

HORVÁTH, F. - DOBOLYI, K. - MORSCHAUER, T. - LÖKÖS, L. - KARAS, L. - SZERDAHELYI, T. (1995): Flóra adatbázis [Flora database]. MTA ÖBKI, Vácrátót. (in Hungarian)

HoubA, V.J.G. - NOVOZAMSKY, I. - HUIJBREGTS, A.W.M. - LEE VAN DER, J.J. (1986): Comparison of soil extractions by $0.01 \mathrm{CaCl}_{2}$ by EUF and by some conventional extraction procedures. Plant and Soil 96: 433-437. https://doi.org/10.1007/BF02375149

Hui, A. Marraffa, J.M. StORK, C.M. (2004): A rare ingestion of the Black Locust tree. Journal of Toxicology: Clinical Toxicology 42: 93-95. https://doi.org/10.1081/CLT-120028752

JÁNOSKA, F. (2012): A mezővédő erdősávok és erdőfoltok jellemzése [Characterization of shelterbelts and forest patches]. In: FARAGó, S. (szerk.): A Lajta Project: Egy tartamos mezei vad és ökoszisztéma vizsgálat 20 éve. [The Lajta Project: 20 years of a long-term field wildlife and ecosystem study], Nyugat-magyarországi Egyetem Kiadó, Sopron. pp.: 159-160. (in Hungarian)

JEZEer, R.E - SANTOS, M.J. - VERweIJA, P.A. - Boot, R.G.A. - CoUGH, Y. (2019): Benefits for multiple ecosystem services in Peruvian coffee agroforestry systems without reducing yield. Ecosystem Services 40: 101033. https://doi.org/10.1016/j.ecoser.2019.101033

KIRÁLY, A. - KIRÁLY, G. (2012): A gyomnövény közösségek szerkezete [The structure of weed communities]. In: FARAGÓ, S. (szerk.): A Lajta Project: Egy tartamos mezei vad és ökoszisztéma vizsgálat 20 éve. [The Lajta Project: 20 years of a long-term field wildlife and ecosystem study] Nyugat-magyarországi Egyetem Kiadó, Sopron. pp.: 134-159. (in Hungarian)

Krähmer, H. - ANDreASEN, C. - ECONOMOU-ANTONAKA, G. - HOLEC, J., KAlivas, D. KoláR̆ová, M. - Novák, R. - PAnozzo, S. - Pinke, G. - SAlonen, J. - SAtTin, M. SteFANIC, E. - VANAGA, I. - FRIED, G. (2019): Weed surveys and weed mapping in Europe: State of the art and future tasks. Crop Protection 129: 105010. https://doi.org/10.1016/j.cropro.2019.105010.

LAZZARO, L. - MAZZA, G. - D’ERrico, G. - Fabiani, A. - GiUliani, C. - Inghilesi, A. F. Lagomarsino, A. - LANDi, S. - LASTRUCCI, L. - PAStORElli, R. - Roversi, P. F. - Torrini, G. - TricARIO, E. - FogGI, B. (2018): How ecosystems change following invasion by Robinia pseudoacacia: Insights from soil chemical properties and soil microbial, nematode, microarthropod and plant communities. Science of the Total Environment 622-623: 1509-1518. https://doi.org/10.1016/j.scitotenv.2017.10.017

LEGENDRE, P. - GALLAGHER, E.D. (2001): Ecologically meaningful transformations for ordination of species data. Oecologia 129: 271-280. https://doi.org/10.1007/s004420100716 
LitT, A.R. - CoRD, E.E. - FulBright, T.E. - SCHUSTER, G.L. (2014): Effects of invasive plants on arthropods. Conservation Biology 28: 1532-1549. https://doi.org/10.1111/cobi.12350

MARSHALL, E.J.P. (1989): Distribution patterns of plants associated with arable field edges. Journal of Applied Ecology 26: 247-257. https://doi.org/10.2307/2403665

MARSHALL, E.J.P. - ARNOLD, G.M. (1995): Factors affecting field weed and field margin flora on a farm in Essex, UK. Landscape and Urban Planning 31 (1-3): 205-216. https://doi.org/10.1016/0169-2046(94)01047-C

MARSHALl, E.J.P. - MOONEN, A.C. (2002): Field margins in northern Europe: their functions and interactions with agriculture. Agriculture Ecosystems and Environment 89: 5-21. https://doi.org/10.1016/S0167-8809(01)00315-2

MARSHALL, E.J.P. - BROWN, V.K. - BOATMAN, N.D - LUTMAN, P.J.W. - SQUIRE, G.R. - WARD, L.K. (2003): The role of weeds in supporting biological diversity within crop fields. Weed Research 43: 77-89 https://doi.org/10.1046/j.1365-3180.2003.00326.x

MenTA, C (2012): Soil Fauna Diversity - Function, Soil Degradation, Biological Indices, Soil Restoration. In: LAMEED, G.A.: Biodiversity Conservation and Utilization in a Diverse World. IntechOpen https://doi.org/10.5772/51091

MiKLAY, F. MOLNÁR, L. (1968): A Mosoni-síkság talajviszonyai [Soil conditions in the Mosoni plain]. Agrokémia és Talajtan 17: 495-506. (in Hungarian)

MORRIS, R.J. - LEWIS, O.T. - GODFRAY, H.C.J. (2004): Experimental evidence for apparent competition in a tropical forest food web. Nature 428: 310-313. https://doi.org/10.1038/nature02394

MORRISON, B.M.L - FLORES S.A. (2013): Promoting biodiversity in agricultural landscapes: native windbreaks support greater understory plant diversity in Monteverde, Costa Rica. Journal of Young Investigators 25 (10). https://www.jyi.org/2013-october/2017/6/25/native-windbreakssupport-greater-understory-plant-diversity-in-monteverde-costa-rica

Nagy, K. - Lengyel, A. - KovÁCs, A. - TÜrei, D. - Csergös, A.M. - Pinke Gy. (2017): Weed species composition of small-scale farmlandsbears a strong crop-related and environmental signature. Weed Research 58 (1): 46-56. https://doi.org/10.1111/wre.12281

NASIRI, H. - IQBAL, Z. - HiRADATE, S. - FUJII, Y. (2005): Allelopathic potential of Robinia pseudoacacia L. Journal of Chemical Ecology 31: 2179-2192. https://doi.org/10.1007/s10886005-6084-5

OLEJNICZAK, I. (2004): Communities of soil microarthropods with special reference to Collembola in midfield shelterbelts. Polish Journal of Ecology 52 (2): 123-133.

OLEJNICZAK, I. (2007): Soil mesofauna (Acarina and Collembola) along transects crossed shelterbelts of different age and adjacent fields. Polish Journal of Ecology 55 (4): 637-646.

PANSU, M. - GaUtheYrou, J. (2007). Handbook of Soil Analysis: Mineralogical, Organic and Inorganic Methods. Springer Science and Business Media: Berlin, Heidelberg, The Netherlands.

PARISI, V. (2001): La qualità biologica del suolo. Un metodo basato sui microatropodi. Acta Naturalia de "L'Ateneo Parmense" 37 (3/4): 105-114.

PÉCSI, M. (1975): A Győri-medence felszínének kialakulása és domborzata [Formation and topography of the surface of the Györ basin]. In: ÁDÁM, L. - MAROSI, S. (Eds): Magyarország tájföldrajza 3. A Kisalföld és a Nyugat-magyarországi-peremvidék. p. 605 (in Hungarian)

PÉCZELI, Gy. (1975): A Sopron - Vasi-síkság éghajlata [The climate of the Sopron - Vas plain]. In: ÁDÁM, L. - MAROSI, S. (eds): Magyarország tájföldrajza 3.: A Kisalföld és a Nyugatmagyarországi-peremvidék. p. 605 (in Hungarian)

Perez, G. - DecaËns, T. - Dujardin, G. - AKPa-Vinceslas, M. - Langlois, E. - Chauvat, M. (2013): Response of collembolan assemblages to plant species successional gradient. Pedobiologia 56 (4-6): 169-177. https://doi.org/10.1016/j.pedobi.2013.04.001

PinKe, G. - KARÁCSONY, P. - CZÚCZ, B. - BOTTA-DUKÁT, Z. - LENGYEL, A. (2012): The influence of environment, management and site context on species composition of summer arable weed vegetation in Hungary. Applied Vegetation Science 15: 136-144. https://doi.org/10.1111/j.1654109X.2011.01158.X

PINKE, GY. - PÁL, R. (2005): Gyomnövényeink eredete, termőhelye és védelme. Alexandra Kiadó, Pécs, 231 p. (in Hungarian) 
Romero, A. - ChAmorro, L. - SANS, F. X. (2008): Weed diversity in crop edges and inner fields of organic and conventional dryland winter cereal crops in NE Spain. Agriculture, Ecosystems and Environment 124: 97-104. https://doi.org/10.1016/j.agee.2007.08.002

Salamon, J.A. - ScAefer, M. - AlPheI, J. - Schmid, B. - ScheU, S. (2004): Effects of Plant Diversity on Collembola in an Experimental Grassland Ecosystem. Oikos 106 (1): 51-60.

SchonRogGe, K. - Stone, G.N. - CRAWLEY, M.J. (1996): Alien herbivores and native parasitoids: rapid developments and structure of the parasitoid and inquiline complex in an invading gall wasp Andricus quercuscalicis (Hymenoptera: Cynipidae). Ecological Entomology 21: 71-80. https://doi.org/10.1111/j.1365-2311.1996.tb00268.x

SutYinSZKi, Zs. - SZENTES, SZ. - KATONA, Z. - PusZTA, E. - MARINKÁs, Á. - PensZKA, K. (2013): Kondorosi mezsgyék növényzete és tájtörténete közötti összefüggések vizsgálata [Examination of the relations between the vegetation and landscape history of field margins in Kondoros]. Tájökológiai Lapok 11 (2): 379-388. (in Hungarian)

TAKÁCS, V. (2008): Útfásítások közlekedésbiztonsági vizsgálata a Sopron-Fertőd Kistérség területén. [Analysis of traffic safety of roadside afforestations in the Sopron-Fertöd region] Doctoral thesis, NyME, Sopron. (in Hungarian)

TÓTHMÉRÉSZ, B. (2013): Diversity. University of Debrecen.

TSCHORA, H. - CHERUBINI, F. (2020): Co-benefits and trade-offs of agroforestry for climate change mitigation and other sustainability goals in West Africa. Global Ecology and Conservation 22: e00919. https://doi.org/10.1016/j.gecco.2020.e00919

WiLlis, A.J. - MemmotT, J. (2005): The potential for indirect effects between a weed, one of its biocontrol agents and native herbivores: A food web approach. Biological Control 35: 299-306. https://doi.org/10.1016/j.biocontrol.2005.07.013

WILSON, P.J. (2019): Restoring pollinator communities and pollination services in hedgerows in intensively managed agricultural landscapes. In: The ecology of hedgerows and field margins. Dover, J.W. (ed.) Routledge, New York, USA. pp. 163-185. 


\section{APPENDIX}

Annex I: GPS coordinates of the sampling plots

\begin{tabular}{cll}
\hline & \multicolumn{1}{c}{ ROBINIA } & \multicolumn{1}{c}{ ACER } \\
\hline & $47.86473,17.12453$ & $47.86191,17.19932$ \\
CULT & $47.86460,17.12541$ & $47.86250,17.20066$ \\
& $47.86444,17.12718$ & $47.86294,17.20189$ \\
\hline \multirow{3}{*}{ EDGE } & $47.86485,17.12455$ & $47.8621,17.19919$ \\
& $47.86473,17.12541$ & $47.86266,17.20052$ \\
& $47.86454,17.12717$ & $47.86313,17.20165$ \\
\hline \multirow{3}{*}{ SHELT } & $47.86501,17.12457$ & $47.86219,17.19912$ \\
& $47.86484,17.1254$ & $47.86277,17.20043$ \\
& $47.86467,17.12718$ & $47.86324,17.20153$ \\
\hline \multirow{3}{*}{ EDGE } & $47.86518,17.12456$ & $47.86229,17.19904$ \\
& $47.86503,17.12538$ & $47.86286,17.20031$ \\
& $47.86484,17.12721$ & $47.86332,17.20145$ \\
\hline \multirow{2}{*}{ CULT } & $47.86531,17.12455$ & $47.86248,17.19887$ \\
& $47.86519,17.12537$ & $47.86304,17.20019$ \\
& $47.86496,17.12722$ & $47.86352,17.20121$ \\
\hline
\end{tabular}


Annex II: Herbaceous species list and cover (\%)

\begin{tabular}{|c|c|c|c|c|c|c|c|c|c|c|c|}
\hline \multirow{2}{*}{ Species } & \multirow{2}{*}{ SBT } & \multicolumn{5}{|c|}{ ROBINIA } & \multicolumn{5}{|c|}{ ACER } \\
\hline & & CULT & EDGE & SHELT & EDGE & CULT & CULT & EDGE & SHELT E & EDGE & CULT \\
\hline Achillea millefolium & DT & 0 & 0 & 0 & 20 & 0 & 0 & 0 & 0 & 0 & 0 \\
\hline Allium scorodoprasum subsp. scorodoprasum & DT & 0 & 0 & 0 & 3 & 0 & 0 & 0 & 0 & 0 & 0 \\
\hline Amaranthus retroflexus & $\mathrm{RC}$ & 0 & 7 & 0 & 0 & 0 & 0 & 0 & 0 & 5 & 0 \\
\hline Anagallis arvensis & W & 0 & 0 & 0 & 0 & 0 & 17 & 0 & 0 & 3 & 0 \\
\hline Anagallis foemina & W & 0 & 0 & 0 & 0 & 0 & 17 & 0 & 0 & 3 & 0 \\
\hline Arrhenatherum elatius & DT & 0 & 13 & 33 & 30 & 0 & 0 & 0 & 0 & 3 & 0 \\
\hline Artemisia vulgaris & W & 0 & 0 & 0 & 0 & 0 & 0 & 0 & 0 & 2 & 0 \\
\hline Avena fatua & W & 0 & 0 & 0 & 0 & 0 & 2 & 0 & 0 & 0 & 0 \\
\hline Ballota nigra & W & 0 & 7 & 13 & 0 & 0 & 0 & 27 & 30 & 27 & 0 \\
\hline Bromus sterilis & $\mathrm{RC}$ & 0 & 13 & 33 & 0 & 0 & 0 & 50 & 40 & 17 & 0 \\
\hline Calamagrostis epigeios & $\mathrm{RC}$ & 0 & 3 & 0 & 0 & 0 & 0 & 0 & 0 & 0 & 0 \\
\hline Cannabis sativa & A & 0 & 0 & 0 & 0 & 0 & 0 & 0 & 0 & 3 & 3 \\
\hline Cardaria draba & W & 0 & 0 & 0 & 0 & 0 & 0 & 2 & 0 & 8 & 0 \\
\hline Carduus acanthoides & W & 0 & 7 & 8 & 0 & 0 & 0 & 12 & 0 & 0 & 0 \\
\hline Carex hirta & DT & 0 & 0 & 0 & 3 & 0 & 0 & 0 & 0 & 0 & 0 \\
\hline Chenopodium album & $\mathrm{RC}$ & 0 & 3 & 0 & 0 & 0 & 0 & 7 & 2 & 2 & 0 \\
\hline Chenopodium hybridum & W & 0 & 0 & 0 & 0 & 0 & 0 & 10 & 0 & 7 & 0 \\
\hline Cirsium arvense & $\mathrm{RC}$ & 0 & 3 & 0 & 0 & 0 & 0 & 0 & 0 & 0 & 0 \\
\hline Cirsium vulgare & W & 0 & 0 & 0 & 0 & 3 & 0 & 0 & 0 & 0 & 0 \\
\hline Consolida regalis & W & 0 & 0 & 0 & 0 & 0 & 0 & 0 & 0 & 3 & 0 \\
\hline Convolvulus arvensis & $\mathrm{RC}$ & 5 & 7 & 2 & 0 & 0 & 0 & 3 & 7 & 7 & 5 \\
\hline Dactylis glomerata & DT & 0 & 0 & 0 & 20 & 0 & 0 & 0 & 0 & 3 & 0 \\
\hline Elymus repens & RC & 0 & 40 & 7 & 3 & 0 & 0 & 13 & 0 & 13 & 0 \\
\hline Euphorbia peplus & W & 0 & 0 & 0 & 0 & 0 & 0 & 0 & 0 & 7 & 0 \\
\hline Falcaria vulgaris & W & 0 & 0 & 0 & 0 & 0 & 0 & 2 & 0 & 0 & 0 \\
\hline Fumaria vaillantii & DT & 0 & 0 & 0 & 0 & 0 & 0 & 0 & 0 & 5 & 0 \\
\hline Galium aparine & W & 0 & 7 & 13 & 0 & 0 & 0 & 10 & 3 & 0 & 0 \\
\hline Geum urbanum & DT & 0 & 0 & 0 & 2 & 0 & 0 & 7 & 17 & 17 & 0 \\
\hline Hypericum perforatum & DT & 0 & 0 & 0 & 5 & 0 & 0 & 0 & 0 & 0 & 0 \\
\hline Lamium purpureum & W & 0 & 15 & 5 & 0 & 0 & 0 & 7 & 7 & 0 & 0 \\
\hline Lathyrus tuberosus & W & 0 & 0 & 0 & 0 & 0 & 0 & 0 & 0 & 2 & 0 \\
\hline Linaria vulgaris & W & 0 & 0 & 0 & 2 & 0 & 0 & 0 & 0 & 0 & 0 \\
\hline Lolium perenne & DT & 0 & 0 & 0 & 7 & 0 & 0 & 0 & 0 & 3 & 0 \\
\hline Medicago sativa & 1 & 0 & 0 & 0 & 0 & 0 & 0 & 0 & 0 & 2 & 0 \\
\hline Mercurialis annua & W & 0 & 0 & 0 & 0 & 0 & 2 & 0 & 0 & 0 & 0 \\
\hline Phacelia tanacetifolia & 1 & 0 & 0 & 0 & 0 & 0 & 0 & 2 & 0 & 3 & 0 \\
\hline Plantago lanceolata & DT & 0 & 0 & 0 & 5 & 0 & 0 & 0 & 0 & 0 & 0 \\
\hline Plantago major & W & 0 & 0 & 0 & 7 & 0 & 0 & 0 & 0 & 0 & 0 \\
\hline Poa pratensis & G & 0 & 0 & 0 & 17 & 0 & 0 & 0 & 0 & 0 & 0 \\
\hline Polygonum aviculare & & 0 & 0 & 0 & 0 & 0 & 0 & 0 & 0 & 7 & 3 \\
\hline Silene latifolia subsp. alba & W & 0 & 0 & 0 & 0 & 0 & 0 & 3 & 0 & 5 & 0 \\
\hline Stellaria media & & 0 & 2 & 5 & 0 & 0 & 0 & 10 & 10 & 8 & 0 \\
\hline Symphytum officinale & G & 0 & 0 & 0 & 0 & 0 & 0 & 0 & 2 & 0 & 0 \\
\hline Taraxacum officinale & $\mathrm{RC}$ & 0 & 0 & 0 & 3 & 0 & 0 & 0 & 0 & 0 & 0 \\
\hline Thymus glabrescens & G & 0 & 0 & 0 & 3 & 0 & 0 & 0 & 0 & 0 & 0 \\
\hline Tripleurospermum inodorum & W & 0 & 0 & 0 & 0 & 0 & 3 & 0 & 0 & 0 & 0 \\
\hline Urtica dioica & DT & 0 & 0 & 3 & 0 & 0 & 0 & 0 & 0 & 0 & 0 \\
\hline Veronica arvensis & DT & 0 & 12 & 0 & 0 & 0 & 0 & 0 & 5 & 2 & 0 \\
\hline Veronica persica & W & 0 & 0 & 0 & 0 & 0 & 0 & 10 & 0 & 3 & 0 \\
\hline Viola arvensis & W & 0 & 0 & 0 & 0 & 0 & 0 & 0 & 0 & 2 & 0 \\
\hline
\end{tabular}


Annex III: Collembola species list

\begin{tabular}{|c|c|c|c|c|c|c|c|c|c|c|}
\hline \multirow{2}{*}{ Species } & \multicolumn{5}{|c|}{ ROBINIA } & \multicolumn{5}{|c|}{ ACER } \\
\hline & CULT & EDGE & SHELT & EDGE & CULT & CULT & EDGE & SHELT & EDGE & CULT \\
\hline Ceratophysella denticulata & 0 & 0 & 0 & 0 & 0 & 2 & 0 & 2 & 0 & 0 \\
\hline Ceratophysella luteospina & 0 & 0 & 7 & 0 & 0 & 0 & 0 & 0 & 0 & 0 \\
\hline Ceratophysella succinea & 14 & 0 & 0 & 0 & 35 & 39 & 0 & 0 & 2 & 11 \\
\hline Hypogastrura socialis & 0 & 54 & 0 & 92 & 4 & 2 & 29 & 0 & 104 & 0 \\
\hline Hypogastrura vernalis & 0 & 0 & 0 & 0 & 0 & 0 & 3 & 0 & 0 & 0 \\
\hline Schoettella ununguiculata & 0 & 14 & 47 & 0 & 0 & 0 & 0 & 17 & 0 & 0 \\
\hline Willemia virae & 8 & 6 & 14 & 9 & 0 & 0 & 1 & 26 & 6 & 1 \\
\hline Friesea sp. & 0 & 0 & 0 & 0 & 0 & 1 & 2 & 0 & 0 & 0 \\
\hline Deutonura conjuncta & 0 & 0 & 6 & 0 & 0 & 0 & 1 & 2 & 0 & 0 \\
\hline Micranurida pygmaea & 0 & 0 & 3 & 0 & 0 & 0 & 1 & 9 & 0 & 0 \\
\hline Pseudachorutes parvulus & 0 & 4 & 28 & 1 & 0 & 0 & 2 & 19 & 0 & 0 \\
\hline Pseudachorutes pratensis & 0 & 0 & 8 & 0 & 0 & 0 & 1 & 0 & 1 & 0 \\
\hline Superodontella lamellifera & 0 & 0 & 0 & 0 & 0 & 0 & 0 & 2 & 0 & 0 \\
\hline Protaphorura armata & 12 & 7 & 38 & 2 & 6 & 3 & 14 & 21 & 3 & 0 \\
\hline Protaphorura campata & 0 & 0 & 12 & 0 & 0 & 0 & 0 & 0 & 0 & 0 \\
\hline Protaphorura cancellata & 0 & 3 & 0 & 0 & 0 & 0 & 4 & 0 & 1 & 0 \\
\hline Protaphorura gisini & 0 & 18 & 0 & 10 & 0 & 1 & 22 & 0 & 9 & 0 \\
\hline Doutnacia xerophyla & 0 & 1 & 67 & 12 & 0 & 0 & 5 & 23 & 1 & 0 \\
\hline Mesaphorura critica & 11 & 16 & 2 & 12 & 2 & 0 & 4 & 0 & 3 & 0 \\
\hline Mesaphorura italica & 4 & 0 & 0 & 0 & 0 & 0 & 0 & 7 & 0 & 0 \\
\hline Mesaphorura krausbaueri & 0 & 9 & 14 & 19 & 0 & 0 & 15 & 4 & 3 & 0 \\
\hline Mesaphorura macrochaeta & 0 & 0 & 0 & 0 & 5 & 22 & 0 & 0 & 0 & 4 \\
\hline Mesaphorura yosii & 3 & 0 & 0 & 0 & 0 & 0 & 0 & 0 & 0 & 0 \\
\hline Metaphorura affinis & 0 & 11 & 126 & 9 & 0 & 0 & 0 & 87 & 0 & 0 \\
\hline Metaphorura denisi & 0 & 12 & 5 & 39 & 2 & 3 & 52 & 0 & 21 & 26 \\
\hline Cryptopygus bipunctatus & 0 & 0 & 0 & 0 & 0 & 0 & 0 & 12 & 0 & 0 \\
\hline Cryptopygus thermophilus & 0 & 7 & 0 & 3 & 0 & 0 & 4 & 0 & 7 & 0 \\
\hline Folsomia manolachei & 0 & 0 & 9 & 0 & 0 & 0 & 0 & 0 & 0 & 0 \\
\hline Folsomides parvulus & 0 & 2 & 12 & 4 & 7 & 0 & 7 & 7 & 3 & 0 \\
\hline Isotomodes productus & 0 & 11 & 0 & 14 & 0 & 0 & 14 & 0 & 8 & 0 \\
\hline Proisotoma minuta & 0 & 0 & 0 & 0 & 0 & 0 & 0 & 8 & 0 & 0 \\
\hline Isotoma caerulea & 0 & 2 & 0 & 0 & 0 & 0 & 2 & 0 & 0 & 0 \\
\hline Isotoma viridis & 0 & 0 & 0 & 9 & 0 & 0 & 0 & 0 & 0 & 0 \\
\hline Parisotoma notabilis & 7 & 17 & 12 & 11 & 19 & 3 & 53 & 27 & 21 & 9 \\
\hline Isotomiella minor & 0 & 28 & 9 & 7 & 0 & 0 & 0 & 0 & 0 & 0 \\
\hline Entomobrya corticalis & 0 & 0 & 1 & 0 & 0 & 0 & 0 & 0 & 0 & 0 \\
\hline Entomobrya multifasciata & 0 & 4 & 0 & 6 & 0 & 0 & 0 & 2 & 0 & 2 \\
\hline Entomobrya quinqelineata & 0 & 0 & 0 & 2 & 0 & 0 & 0 & 0 & 1 & 0 \\
\hline Orchesella cincta & 1 & 3 & 4 & 1 & 3 & 0 & 1 & 2 & 3 & 0 \\
\hline Lepidocyrtus cyaneus & 3 & 2 & 0 & 0 & 0 & 0 & 0 & 0 & 0 & 0 \\
\hline Lepidocyrtus lanuginosus & 0 & 0 & 0 & 0 & 0 & 0 & 12 & 7 & 4 & 0 \\
\hline Lepidocyrtus cf. lignorum & 0 & 0 & 6 & 0 & 0 & 0 & 7 & 19 & 5 & 0 \\
\hline Lepidocyrtus paradoxus & 0 & 0 & 0 & 1 & 0 & 0 & 0 & 0 & 0 & 0 \\
\hline Heteromurus major & 0 & 0 & 5 & 0 & 0 & 0 & 3 & 2 & 5 & 0 \\
\hline Tomocerus juv & 0 & 0 & 0 & 0 & 0 & 0 & 0 & 1 & 0 & 0 \\
\hline Pseudosinella alba & 0 & 18 & 13 & 8 & 0 & 2 & 11 & 8 & 3 & 0 \\
\hline Pseudosinella octopunctata & 1 & 2 & 0 & 5 & 0 & 0 & 0 & 0 & 2 & 0 \\
\hline Pseudosinella petterseni & 0 & 4 & 0 & 0 & 0 & 0 & 0 & 1 & 0 & 1 \\
\hline Pseudosinella zygophora & 0 & 0 & 3 & 2 & 3 & 0 & 1 & 0 & 3 & 2 \\
\hline Cyphoderus albinus & 0 & 1 & 0 & 3 & 0 & 0 & 0 & 0 & 0 & 0 \\
\hline Megalothorax minimus & 0 & 0 & 0 & 0 & 0 & 0 & 4 & 9 & 0 & 0 \\
\hline Bourletiella arvalis & 0 & 2 & 0 & 0 & 0 & 0 & 0 & 0 & 0 & 0 \\
\hline Sphaeridia pumilis & 0 & 9 & 0 & 14 & 0 & 0 & 17 & 28 & 4 & 0 \\
\hline Sminthurinus elegans & 0 & 7 & 0 & 6 & 1 & 2 & 2 & 0 & 2 & 0 \\
\hline
\end{tabular}


Annex IV: calculation of QBS-ar index

\begin{tabular}{lcccccccccc}
\hline \multicolumn{1}{c}{$\begin{array}{c}\text { Microarthropod taxa } \\
\text { individuals }\end{array}$} & CULT & EDGE & SHELT & EDGE & CULT & CULT & EDGE & SHELT & EDGE & CULT \\
\hline ACARI & 276 & 823 & 1128 & 530 & 214 & 329 & 643 & 1236 & 571 & 179 \\
ARANEAE & 1 & 3 & 2 & 1 & 0 & 0 & 3 & 4 & 2 & 0 \\
CHILOPODA & 0 & 1 & 2 & 0 & 0 & 0 & 0 & 1 & 0 & 0 \\
COLEOPTERA & 3 & 3 & 3 & 1 & 0 & 1 & 5 & 5 & 2 & 1 \\
COLEOPTERA larvae & 3 & 11 & 9 & 8 & 0 & 1 & 3 & 14 & 4 & 1 \\
COLLEMBOLA & 64 & 274 & 451 & 301 & 87 & 80 & 294 & 352 & 225 & 56 \\
DIPLOPODA & 0 & 2 & 0 & 0 & 0 & 0 & 0 & 1 & 0 & 0 \\
DIPLURA & 2 & 6 & 5 & 9 & 5 & 0 & 7 & 7 & 4 & 0 \\
DIPTERA LARVAE & 0 & 0 & 2 & 2 & 0 & 1 & 1 & 0 & 3 & 0 \\
HEMIPTERA & 0 & 0 & 0 & 1 & 0 & 0 & 0 & 0 & 2 & 0 \\
HYMENOPTERA - ANTS & 0 & 12 & 2 & 6 & 5 & 0 & 6 & 0 & 17 & 0 \\
LARVA HYMENOPTERA & 0 & 0 & 0 & 2 & 0 & 0 & 0 & 0 & 0 & 0 \\
ISOPODA & 0 & 0 & 0 & 0 & 0 & 0 & 0 & 0 & 0 & 0 \\
LARVA LEPIDOPTERA & 0 & 0 & 0 & 0 & 0 & 0 & 1 & 0 & 0 & 0 \\
PAUROPODA & 1 & 2 & 0 & 0 & 0 & 0 & 0 & 0 & 0 & 0 \\
PROTURA & 0 & 0 & 0 & 0 & 0 & 0 & 2 & 4 & 0 \\
PSEUDOSCORPIONIDA & 0 & 0 & 0 & 0 & 0 & 0 & 0 & 3 & 0 \\
PSOCOPTERA & 16 & 5 & 7 & 0 & 8 & 4 & 2 & 0 & 9 \\
SYMPHYLA & 0 & 5 & 3 & 2 & 0 & 0 & 6 & 7 & 2 \\
THYSANOPTERA & 0 & 2 & 7 & 2 & 0 & 0 & 1 & 3 & 4 & 0 \\
\hline & & & & & & & & & 0 \\
\end{tabular}

\begin{tabular}{lcccccccccc}
\hline \multicolumn{1}{c}{$\quad$\begin{tabular}{c} 
Microarthropod taxa \\
\multicolumn{1}{c}{ EMI scores }
\end{tabular}} & CULT & EDGE & SHELT & EDGE & CULT & CULT & EDGE & SHELT & EDGE & CULT \\
\hline ACARI & 20 & 20 & 20 & 20 & 20 & 20 & 20 & 20 & 20 & 20 \\
ARANEAE & 1 & 5 & 5 & 1 & 0 & 0 & 5 & 1 & 5 & 0 \\
CHILOPODA & 0 & 10 & 10 & 0 & 0 & 0 & 0 & 10 & 0 & 0 \\
COLEOPTERA & 1 & 5 & 5 & 5 & 0 & 1 & 5 & 5 & 1 & 1 \\
COLEOPTERA larvae & 10 & 10 & 10 & 10 & 0 & 10 & 10 & 10 & 10 & 10 \\
COLLEMBOLA & 20 & 20 & 20 & 20 & 20 & 20 & 20 & 20 & 20 & 20 \\
DIPLOPODA & 0 & 10 & 0 & 0 & 0 & 0 & 0 & 10 & 0 & 0 \\
DIPLURA & 20 & 20 & 20 & 20 & 20 & 0 & 20 & 20 & 20 & 0 \\
DIPTERA LARVAE & 0 & 0 & 10 & 10 & 0 & 10 & 10 & 0 & 10 & 0 \\
HEMIPTERA & 0 & 0 & 0 & 1 & 0 & 0 & 0 & 0 & 1 & 0 \\
HYMENOPTERA - ANTS & 0 & 5 & 5 & 5 & 5 & 0 & 5 & 0 & 5 & 0 \\
LARVA HYMENOPTERA & 0 & 0 & 0 & 10 & 0 & 0 & 0 & 0 & 0 & 0 \\
ISOPODA & 0 & 0 & 0 & 0 & 0 & 0 & 0 & 0 & 0 & 0 \\
LARVA LEPIDOPTERA & 0 & 0 & 0 & 0 & 0 & 0 & 1 & 0 & 0 & 0 \\
PAUROPODA & 20 & 20 & 0 & 0 & 0 & 0 & 0 & 0 & 0 & 0 \\
PROTURA & 0 & 0 & 0 & 0 & 0 & 0 & 20 & 20 & 0 & 0 \\
PSEUDOSCORPIONIDA & 0 & 0 & 0 & 0 & 0 & 0 & 0 & 20 & 0 & 0 \\
PSOCOPTERA & 1 & 1 & 1 & 0 & 1 & 1 & 1 & 0 & 1 & 1 \\
SYMPHYLA & 0 & 10 & 10 & 10 & 0 & 0 & 10 & 10 & 10 & 0 \\
THYSANOPTERA & 0 & 1 & 1 & 1 & 0 & 0 & 1 & 1 & 1 & 0 \\
QBS-ar & 93 & 137 & 117 & 113 & 66 & 62 & 128 & 147 & 104 & 52 \\
\hline
\end{tabular}

